\title{
Does Psychological Capital Combat Learning and Adaptive Stress of College Freshmen
}

\author{
Melody Ling-Yu Wen \\ Professor of Department of Finance \\ National Changhua University of Education, Changhua, Taiwan \\ E-mail: bumelody@cc.ncue.edu.tw \\ Danny Yung-Chuan Lin \\ Department of Finance \\ National Changhua University of Education, Changhua, Taiwan \\ E-mail: danny.mailbox@msa.hinet.net
}

Received: Dec. 6, 2013 Accepted: December 20, 2013 Published: February 1, 2014

doi:10.5296/jse.v4i1.4684

URL: http://dx.doi.org/10.5296/jse.v4i1.4684

\begin{abstract}
Psychological capital (PsyCap) is an important resource for combating one's stress in organizational context which constructed with core constructs including self-efficacy, optimism, hope and resilience. Colleges freshmen have much stress while their transition from high schools (youth hood) to colleges (adult hood). While the participants from colleges, this study comprised academic self-efficacy, optimism, hope, and academic resilience into PsyCap constructs and examined its effectiveness on learning and adaptive stress of colleges freshmen. 640 survey questionnaires were distributed to participants, 427 usable questionnaires returned, with $66.7 \%$ valid return rate graded by the participants from Department of International Business Management (IBM) of 8 universities located in center of Taiwan. The results disclosed, except to the living expense stress, overall PsyCap efficaciously copes with learning and adaptive stress of colleges freshmen. Besides, overall PsyCap has found stronger predictabilities to learning and adaptive stress than its individual element. This study contributed to confirm the role of PsyCap as an important resource in combating with stress across different disciplines, and, in both theoretical and practical implications. The concrete conclusions and recommendations of this study were made for
\end{abstract}


theoretical and practical courses design of IBM, and further studies.

Keywords: Psychological capital/PsyCap, Learning and adaptive stress, Academic self-efficacy, Optimism, Hope, Academic resilience 


\section{Introduction}

Globalization enhances massive national and regional competition since last decade. Under the massive stresses caused by economical wars nowadays, none would be possible to stay out of this challenge. "Stress" seems to be a critical concern for many different professions even in educational context. School contains many different roles such as academies, staffs, and its main containment are students. Previous studies revealed the increasing trend of mental health problems of college students (Newbury-Birch, Lowry, \& Kamali, 2002 ; Raj, Simpson, Hopman, \& Singer, 2000) that remind academies and scholars to pay attention to the stress matters in educational context.

However, numerous of factors may explain the health disorders of college students related not only to their schools but also to the family, peers, and interpersonal relationships (Vaez \& Laflamme, 2008). Besides, previous studies indicated that psychological distress among college students is significantly higher than other population (Adlaf, Gliksman, Demers, \& Newton-Taylor, 2001; Stewart-Brown, Patterson, Petersen, Doll, Balding, \& Regis, 2000). This psychological distress may be caused by their social roles changed during their college study since students are forced to cope with new environment where to obtain professional knowledge, change living arrangements or start new relationships, and some become responding their own cost for college years (Disch, Harlow, Campbell, \& Dougan, 2000).

Moreover, to the most of the young adults, psychological stress may come from the reasons that colleges are important field where students are forced to transit themselves into adulthood and important decision-making for coming future. Such experiences are totally different from high school life that they are obliged to leave from home and parents, expend academic demands, quiz about personal identity, and make decisions for future career choice (Adlaf et al., 2001 ; Stewart-Brown et al., 2000). Therefore, from high school to colleges indeed a stressful context for most of college freshmen. This generated our study motivation to know the stressors of college freshmen.

Schools are obligated with "broad mission" to develop young people who are "knowledgeable, responsible, healthy, caring, connected, and contributing" (Weissberg \& O'Brien, 2004, p.87). The main developmental goals of schools are facilitating an integrated combination of social, emotional, and academic learning of students (Weissberg \& O'Brien, 2004). Therefore, schools are responsible for concerning on the stressful matters of students. On the other hand, how students cultivate themselves into a capable individual in coping stressors are also important during their study.

"Problem focused" and "Emotion focused" coping strategies are changing the environment to resolve the stressful situation by the former and adjusting one's emotions and recognitions of the meaning of the events by the latter. Psychological capital (PsyCap) as an important resource of combating stress (Avey, Luthans \& Jensen, 2009) which comprises self-efficacy, optimism, hope, and resilience (Luthans, Norman, Avolio, \& Avey, 2008) is emerging in organizational behavior studies. It contains "Problem focused" as self-efficacy and hope to struggle with events, and "Emotion focused" as optimism and resilience to adjust one's feeling to particular events. To our knowledge, PsyCap is not much utilized into the 
educational study context. This attractiveness enhanced our study to examine the meaningful resource of combating stress with college freshmen who stand for massive pressures from high school transit to new environment.

Besides, Larson and Luthans (2006) as pioneers in PsyCap studies who suggested when the positive organizational behavior (POB) variables are combined into a core construct, overall PsyCap may become a stronger predictor than any one of the four components individually. To compare the predictive strength of overall PsyCap and four individual components to the stress of college freshmen, this study proposed a POB variable into educational study to find out the different predictive abilities between overall PsyCap and its individual component in educational context.

\section{Literature review}

\subsection{Learning and adaptive stress}

Based on the Cognitive Theory of Emotions, stress is defined as "a relationship between the person and the environment that is appraised by the person as relevant to his or her well-being and in which the person's resources are taxed or exceeded" (Folkman \& Lazarus, 1985, p.152). In another words, individual perceive a situation as stressful while particular event threatens or surpasses one's internal or external resources. Therefore, stress is the relationship and interaction result between environment and individual. It may cause one's physical and emotional problems such as dissatisfaction, sense of failure, anxiety, tension, frustration, and depression (Ko, Yu, \& Kim, 2003).

According to the notion of environment-individual interaction, academic stress has been studied extensively as an important factor in university context (Gall, Evans, \& Bellerose, 2000). Students struggle for academic successful lead to achievement (Trusty, 2000), while negative outcome as excessive stress and related mental health matters are also arisen (Shek, 1995). In educational context, undergraduate confronts different academic stress. Previous studies investigated and suggested academic stress contain examinations (Evans \& Kelly, 2004), extreme amount academic work (Evans \& Kelly, 2004), and difficulty of academic work (Evans \& Kelly, 2004). Burnard, Rahim, Hayes and Edwards (2007) also revealed variety of stressors including pressure of grades or fear of failing (Sheu, Lin, \& Hwang, 2002), time pressure (Jones \& Johnston, 2000), long hours study (Beck \& Srivastava, 1991), and the relationship with academic staffs (Evans \& Kelly, 2004).

In addition to the academy related stress, undergraduate students especially for freshmen in particular, may senses the stress of start new relationships such as friendships, romantic relationships, family relationships (Dunkel-Schetter \& Lobel, 1990), and even financial concerns (Brown \& Edelmann, 2000) due to the transitional nature of college life. Such psychological distress may be arisen since their social roles are changed, and undergraduate students are forced to deal with new environment, start new relationships, and some may become responding their expenses for the college years (Disch et al., 2000). How to combat the learning and adaptive stress became a critical issue for college freshmen. 


\subsection{Psychological capital/PsyCap}

Numerous studies indicated that academic performance is significantly affected by academic stress while academic performance is also affected by psychological factors (McKenzie \& Schweitzer, 2001). Therefore, the applicable means to combat psychological distress may rely on psychological resource. PsyCap was disclosed as a significant resource in combating stress which is an emerging topic in organizational studies (Avey et al., 2009). The others, Lazarus (2003) also specifically suggested its important role as a relevant route of exploration for promoted understanding of how individual adapt to stress. As a pioneer in PsyCap studies, Luthans and his colleagues defined PsyCap as "an individual's positive psychological state of development and is characterized by: (1) having confidence (self-efficacy) to take on and put in the necessary effort to succeed at challenging tasks; (2) making a positive attribution (optimism) about succeeding now and in the future; (3) persevering toward goals and, when necessary, redirecting paths to goals (hope) in order to succeed; and (4) when beset by problems and adversity, sustaining and bouncing back and even beyond (resilience) to attain success" (Luthans, Youssef, \& Avolio, 2007, p. 3). Each individually component of this critical resource (PsyCap) is more fully described below.

\subsubsection{Self-efficacy}

Based on Social Cognitive Theory, self-efficacy is applied to the workplace and defined as "an individual's conviction about his or her abilities to mobilize the motivation, cognitive resources, and courses of action necessary to successfully execute a specific task within a given context" (Stajkovic \& Luthans, 1998, p. 66). In other words, individuals are tended to pursue their goals if they consider their own abilities and actions are capable of achieving the desired results (Bandura, Caprara, Barbaranelli, Gerbino, \& Pastorelli, 2003). Besides, self-efficacy is fostered accumulatively by the particular successes which experienced by individual in the pass, in contrast, failure experiences tend to lessen one's judgment on particular task which may reduce his/her self-efficacy that makes individual stuck in difficult position (Bandura, 2008). This rolling accumulation enhance individual progressively obtained and integrated the complex cognitive, social, and physiological skills that become the fundamental resource of how people decide to respond to the particular task (Bandura, 1982).

A considerable literatures of self-efficacy revealed that different domains of human functioning applied to diverse self-efficacy beliefs (Bandura, 1997). In educational context, academic self-efficacy beliefs describe whether one's expectations and convictions about their competence can accomplish in academic domains (Lorsbach \& Jinks, 1999). Students evaluate themselves as a capable one to carry out their academic achievements, choice different courses, and deal with different challenges (Folkman \& Moskowitz, 2004). By increasing the motivation and persistence, academic self-efficacy enhances students to master academic tasks with the accumulative knowledge and skills (Bandura, 1993). Undoubtedly, academic self-efficacy is shown positively associated with grades in college in extensive body of empirical researches (Bong, 2001; Hackett, Betz, Casas, \& Rocha-Singh, 1992). 


\subsubsection{Optimism}

Optimism as a component of PsyCap comprises both realistic and flexible characters (Luthans, Youssef, et al., 2007). According to the notion of Attribution Theory, optimism attributes positive events to personal, permanent, and pervasive causes, in contrast, negative events are referred to external, temporary, and situation-specific ones (Seligman, 1998). As Carver and Scheier (2002) indicate optimism so simply that "optimists are people who expect good things to happen to them; pessimists are people who expect bad things to happen to them" (Carver \& Scheier, 2002, p. 231). Optimism plays a variety role in the lives of individuals in the area of educational, occupational, and psychological adjustment. Shepperd, Maroto and Pbert (1996) reported that optimism has a positive relationship with individuals' success in tasks including academic achievement. This may be linked to the coping style of optimistic individuals while they faced to the challenges occurred. As Park (1998) revealed that individual with superior coping styles are better able to deal with challenges and adversities. Therefore, individual with high level optimism tend to easily escape from stress situation caused by challenges and adversities in their life.

\subsubsection{Hope}

As a facet of PsyCap which is different from the oral usage in everyday language, hope has its specific meaning with substantial theoretical support (Snyder, 2000). It is defined as "positive motivational state that is based on an interactively derived sense of successful (1) agency (goal-directed energy) and (2) pathways (planning to meet goals)" (Snyder, Irving, \& Anderson, 1991, p. 287). In other words, hope comprises "willpower" and "waypower" thinking of how individual determinates his/her goals by former and being able to create alternative pathways and contingency plans to achieve a goal with barriers by latter. Similar to self-efficacy and optimism, hope has become an essential coping strategy in academic context (Onwuegbuzie \& Snyder, 2000 ; Snyder, Lopez, Shorey, Rand, \& Feldman, 2003) as researchers have investigated its importance for research and practice that students with high level of hope were found to correlate positively with academic achievement (McDermott \& Snyder, 2000).

\subsubsection{Resilience}

The final component of PsyCap is resilience, which defined as "the capacity to rebound or bounce back from adversity, conflict, failure, or even positive events, progress, and increased responsibility" (Luthans, 2002, p. 702). In other words, resilient people tend to bounce back from setbacks and positively deal and adapt with the challenges and adversities caused by the significant changes. According to present study purpose to examine organizational behavior variables into educational context, resilience is similar to self-efficacy which was investigated in different domains including academic achievement. For example, Martin and Marsh (2006) implemented investigation in high-school students and found academic resilience subsequently predicts educational and psychological outcomes such as enjoyment of school, class participation, and general self-esteem. In addition, Gayles (2005) also found that academic resilience is a catalyzer, which promotes students' academic achievement. 


\subsection{Hypotheses}

In organizational studies, Lazarus and Folkman (1984) suggested that PsyCap is one of the critical resources for employees to cope with stressful events or conditions at work. Besides, Avey, Luthans and Jensen (2009) also found employees' PsyCap has a negative relationship with their symptoms of stress. In accordance with the intention of this study to examine the POB variable into educational context, this study hypothesized the relationship between PsyCap and learning/adaptive stress as below.

H1: Overall PsyCap negative influences learning/adaptive stress of college freshmen.

With regards to the learning and adaptive stress among college freshmen, previous studies revealed different stressors in different contexts with undergraduate students such as relationships (Dunkel-Schetter \& Lobel, 1990), examinations (Evans \& Kelly, 2004), extreme amount academic work (Evans \& Kelly, 2004), difficulty of academic work (Evans \& Kelly, 2004), and even financial concerns (Brown \& Edelmann, 2000). In educational study, Lin (2005) validated learning and adaptive stress scales from college freshmen in Taiwan with five components as learning problem, living expense, relationships, personality distress, and career development stresses. To implement this study in the educational context in Taiwan, we rather to hypothesize the relationship of overall PsyCap to the five individually component of learning and adaptive stress which has been validated in a proximal zone of this study as below.

H1a: Overall PsyCap negative influences learning problem stress of college freshmen.

H1b: Overall PsyCap negative influences living expense stress of college freshmen.

H1c: Overall PsyCap negative influences relationships stress of college freshmen.

H1d: Overall PsyCap negative influences personality distress of college freshmen.

H1e: Overall PsyCap negative influences career development stress of college freshmen.

Larson and Luthans (2006) are pioneers in PsyCap studies who argued when positive organizational behavior (POB) variables are combined into a core construct, overall PsyCap may become a stronger predictor than any one of the four components individually. To compare the predictive strength of overall PsyCap and four individual components to the learning and adaptive stress of first-grade university students, the relationship of individual component of PsyCap to the learning/adaptive stress are necessary to be disclosed. Bandura (2008) argued that individuals with lower efficacy are easily surrendered in difficult position and more likely to experience negative stress symptoms, while people with higher level of efficacy may struggle in dealing with challenges and adversities with their sufficient competencies and effort. Empirical study suggested that optimism may protect from the negative influence of stress (Schulz, Vögele, \& Meyer, 2009). Furthermore, Affleck and Tennen (1996) found that hope is a useful component in helping individual to enhance the positive appraisals of stressful situations. They also postulated that hope may act a "unique role in shaping positive appraisals of adversity" (Affleck \& Tennen 1996, p. 911). Finally, research disclosed that resilient individuals are better prepared to cope with those stressors 
caused by the constantly changing workplace environment (Tugade \& Fredrickson, 2004), while Wagnild and Young (1993) described resilience as "a personality factor that moderates the negative effects of stress and promotes adaptation" (Wagnild \& Young, 1993, p. 178). Therefore, this study intended to hypothesize and compare the predictive strength of overall PsyCap and its individually component to the college freshmen as below.

H2a: Overall PsyCap will have a stronger relationship with learning/adaptive stress of college freshmen than academic self-efficacy.

H2b: Overall PsyCap will have a stronger relationship with learning/adaptive stress of college freshmen than optimism.

H2c: Overall PsyCap will have a stronger relationship with learning/adaptive stress of college freshmen than hope.

H2d: Overall PsyCap will have a stronger relationship with learning/adaptive stress of college freshmen than academic resilience.

\section{Method}

\subsection{Participants}

Variety of studies focused on the academic stress of college students (Gall, Evans, \& Bellerose, 2000 ; Mallinckrodt, 1988), but limited in discussing the learning and adaptive stress of college freshmen particularly. Because of the nature of college freshmen stress is come from the transition from high school to college context (Towbes \& Cohen, 1996); moreover, the constraint of facing uncertainty future is also raising high pressure to them. This study chose the first-grade students from the Department of International Business Management of 8 universities located in center of Taiwan. Students from Department of International Business Management may sense more learning and adaptive stress due to their major are facing international competitive in the future. Six hundred and forty survey questionnaires were distributed to the participants, 427 contained usable data, with $66.7 \%$ usable return rate including 133 male students (31.4\%) and 291 female students (68.6\%).

\subsection{Measures-Instruments}

\subsubsection{Psychological capital (PsyCap)}

PsyCap comprises self-efficacy, optimism, hope, and resilience domains which is a core construct variable. In organizational studies, PCQ (psychological capital questionnaire) developed by Luthans, Avolio, Avey and Norman (2007) were frequently implemented in previous studies. Nevertheless, Multon, Brown and Lent (1991) concluded their meta-analysis and found academic self-efficacy is more predictive than general self-efficacy in educational context. Besides, researchers also conducted academic resilience scales in educational studies (Martin \& Marsh, 2006). Therefore, this study re-combined the four components of PsyCap for educational application with academic self-efficacy, optimism, hope, and academic resilience, which is still complied with the original construct. Five items from Muris (2001) were revised and utilized to rate the level of academic self-efficacy such 
as "I can succeed in finishing all my homework." Five items revised from Life Orientation Test-Revised (LOT-R) which was developed by Scheier, Carver and Bridges (1994) to score the level of optimism such as "I'm always optimistic about my future." Hope was revised from the scale which revealed by Snyder, Sympson, Ybasco, Borders, Babyak and Higgins (1996) with four items such as "There are lots of ways around any problem that I am facing." And academic resilience was revised from the scale developed by Martin and Marsh (2006) with four items such as "I don't let study stress get on top of me." Statistics revealed a good internal consistency reliability in Cronbach's alpha .859 with an acceptable model fit indices by Confirmatory factor analysis $\left(\chi^{2} /\right.$ d.f. $=3.527, \mathrm{GFI}=.894, \mathrm{RMR}=.040, \mathrm{RMSEA}=.077$, $\mathrm{AGFI}=.860, \mathrm{CFI}=.889, \mathrm{SRMR}=.0620)$. Participants indicate the extent to which they agree with each of the statements on a 5-point Likert scale (1 _ strongly disagree to 5 _ strongly agree).

\subsubsection{Learning and adaptive stress}

Learning and adaptive stress scale (LASS) which was developed by Lin (2005) validated from the first-grade university students in Taiwan was utilized to indicate the stress of college freshmen in this study. The scale comprises learning problem, living expense, relationships, personality distress, and career development stresses. Each component comprises four items such as "It is hard for me in adapting the academician teaching in class", "I need to respond the expenses myself for the university years", "I don't know how to express myself in crowds", "I am easy to lose my emotion control" , and "I don't know how I can prepare and make decision for future career choice." Statistics revealed a good internal consistency reliability in Cronbach's alpha .849 with an acceptable model fit indices by Confirmatory factor analysis $\left(\chi^{2} /\right.$ d.f. $=2.588, \mathrm{GFI}=.910, \mathrm{RMR}=.058, \mathrm{RMSEA}=.061, \mathrm{AGFI}=.882$, $\mathrm{CFI}=.945, \mathrm{SRMR}=.0690)$. Participants indicate the extent to which they agree with each of the statements on a 5 -point Likert scale ( $1_{\text {_ }}$ strongly disagree to 5 _ strongly agree).

\section{Result}

Structural equation modeling (SEM) was applied to examine and verify hypotheses for the causal relationships between variables. It is a multivariate statistical tool combines aspects of multiple regression and factor analysis. Besides, descriptive statistical is also processed to show means, standard deviations and correlations for variables in Table 1. The result shows no collinear problem between independent variables because of the inter-correlation is less than .8 which was suggested by Katz (1999). In examining the model fit, AMOS 18 was applied to test on the path coefficients according to the hypotheses with brought results as Table 2 as below.

The results show that structural models have an acceptable statistics model fit indices. By testing the prediction role of overall PsyCap to the learning and adaptive stress, critical ration for regression weight $(\mathrm{C} . \mathrm{R} .=-5.349, p<.001)$ demonstrated that hypothesis 1 was supported, overall PsyCap has a negative relationship with learning and adaptive stress. Besides, the sub-hypotheses of the relationship between PsyCap to learning and adaptive stress were hypothesized as overall PsyCap predicts to the individually learning and adaptive stress component. Statistics revealed that critical ration for regression weight of overall PsyCap to the living expense stress is not significant. Except hypothesis 1b, other hypotheses with 


\section{Macrothink}

regards to the overall PsyCap predicts to individually component of learning and adaptive stress was supported. Finally, compare to the predication abilities of overall PsyCap and its individual component to the learning and adaptive stress, the critical ration for regression weight individually to the learning and adaptive stress is less than -5.349 which computed from the overall PsyCap to learning and adaptive stress. It demonstrated hypotheses $2 \mathrm{a}$ to $2 \mathrm{~d}$ were supported and overall PsyCap as a core construct has a greater prediction than its individual component.

Table 1. Means, standard deviations, correlation matrix

\begin{tabular}{|c|c|c|c|c|c|c|c|c|c|c|c|c|c|}
\hline & Mean & SD & 1 & 2 & 3 & 4 & 5 & 6 & 7 & 8 & 9 & 10 & 11 \\
\hline OPC & 3.14 & .44 & 1 & & & & & & & & & & \\
\hline ASE & 2.99 & .59 & $\begin{array}{l}.650 \\
(* *)\end{array}$ & 1 & & & & & & & & & \\
\hline $\mathrm{OM}$ & 3.26 & .56 & $\begin{array}{l}.775 \\
(* *)\end{array}$ & $\begin{array}{l}.331 \\
(* *)\end{array}$ & 1 & & & & & & & & \\
\hline HP & 3.30 & .63 & $\begin{array}{l}.790 \\
(* *)\end{array}$ & $\begin{array}{l}.426 \\
(* *)\end{array}$ & $\begin{array}{l}.537 \\
(* *)\end{array}$ & 1 & & & & & & & \\
\hline ARS & 3.02 & .67 & $\begin{array}{l}.678 \\
(* *)\end{array}$ & $\begin{array}{l}.158 \\
(* *)\end{array}$ & $\begin{array}{l}.413 \\
(* *)\end{array}$ & $\begin{array}{l}.325 \\
(* *)\end{array}$ & 1 & & & & & & \\
\hline LAS & 2.67 & .47 & $\begin{array}{c}-.404 \\
(* *)\end{array}$ & $\begin{array}{c}-.275 \\
(* *)\end{array}$ & $\begin{array}{c}-.290 \\
(* *)\end{array}$ & $\begin{array}{c}-.334 \\
(* *)\end{array}$ & $\begin{array}{c}-.268 \\
(* *)\end{array}$ & 1 & & & & & \\
\hline LPS & 2.88 & .62 & $\begin{array}{c}-.228 \\
(* *)\end{array}$ & $\begin{array}{c}-.327 \\
(* *)\end{array}$ & $\begin{array}{c}-.096 \\
(*)\end{array}$ & $\begin{array}{c}-.211 \\
(* *)\end{array}$ & -.034 & $\begin{array}{l}.550 \\
(* *)\end{array}$ & 1 & & & & \\
\hline LES & 2.38 & .90 & .028 & .004 & .027. & $\begin{array}{c}.124 \\
(*)\end{array}$ & -.069 & $\begin{array}{l}.531 \\
(* *)\end{array}$ & $\begin{array}{c}.109 \\
(*)\end{array}$ & 1 & & & \\
\hline RSS & 2.56 & .70 & $\begin{array}{c}-.326 \\
(* *)\end{array}$ & $\begin{array}{c}-.138 \\
(* *)\end{array}$ & $\begin{array}{c}-.246 \\
(* *)\end{array}$ & $\begin{array}{c}-.297 \\
(* *)\end{array}$ & $\begin{array}{c}-.256 \\
(* *)\end{array}$ & $\begin{array}{l}.685 \\
(* *)\end{array}$ & $\begin{array}{l}.215 \\
(* *)\end{array}$ & $\begin{array}{l}.170 \\
(* *)\end{array}$ & 1 & & \\
\hline PDS & 2.26 & .68 & $\begin{array}{c}-.420 \\
(* *)\end{array}$ & $\begin{array}{c}-.228 \\
(* *)\end{array}$ & $\begin{array}{c}-.394 \\
(* *)\end{array}$ & $\begin{array}{c}-.385 \\
(* *)\end{array}$ & $\begin{array}{c}-.217 \\
(* *)\end{array}$ & $\begin{array}{l}.681 \\
(* *)\end{array}$ & $\begin{array}{l}.279 \\
(* *)\end{array}$ & $\begin{array}{l}.192 \\
(* *)\end{array}$ & $\begin{array}{l}.448 \\
(* *)\end{array}$ & 1 & \\
\hline CDS & 3.23 & .90 & $\begin{array}{c}-.355 \\
(* *)\end{array}$ & $\begin{array}{c}-.217 \\
(* *)\end{array}$ & $\begin{array}{c}-.232 \\
(* *)\end{array}$ & $\begin{array}{c}-.329 \\
(* *)\end{array}$ & $\begin{array}{c}-.245 \\
(* *)\end{array}$ & $\begin{array}{l}.658 \\
(* *)\end{array}$ & $\begin{array}{l}.257 \\
(* *)\end{array}$ & .039 & $\begin{array}{l}.359 \\
(* *)\end{array}$ & $\begin{array}{l}.295 \\
(* *)\end{array}$ & 1 \\
\hline
\end{tabular}

Note: OPC, Overall psychological capital ; ASE, Academic self-efficacy ; OM, Optimism ; HP, Hope ; ARS, Academic resilience ; LAS, Learning and adaptive stress ; LPS, Learning problem stress ; LES, Living expense stress ; RSS, Relationships stress ; PDS, Personality distress stress ; CDS, Career development stress.

$* p<.05, \quad * * p<.01$ 


\section{Macrothink}

Table 2. Results for fit indices of structural models.

\begin{tabular}{|c|c|c|c|c|c|c|c|c|c|}
\hline $\begin{array}{l}\text { Model and } \\
\text { Construct }\end{array}$ & C. R. & $\chi^{2} /$ d.f. & GFI & RMR & $\begin{array}{c}\text { RMSE } \\
\text { A }\end{array}$ & AGFI & CFI & SRMR & $\mathrm{H}$ \\
\hline $\begin{array}{l}\text { OPC to } \\
\text { LAS }\end{array}$ & $\begin{array}{l}-5.349 \\
(* * *)\end{array}$ & 4.794 & .938 & .031 & .095 & .892 & .865 & .0638 & $\mathrm{H} 1$ \\
\hline $\mathrm{OPC}$ to & & & & & & & & & \\
\hline $\begin{array}{c}\text { LAS } \\
\text { components }\end{array}$ & & 2.775 & .879 & .072 & .065 & .853 & .915 & .0901 & \\
\hline OPC to LPS & $\begin{array}{l}-4.653 \\
(* * *)\end{array}$ & & & & & & & & H1a \\
\hline OPC to LES & -.230 & & & & & & & & $\mathrm{H} 1 \mathrm{~b}$ \\
\hline OPC to RSS & $\begin{array}{l}-3.445 \\
(* * *)\end{array}$ & & & & & & & & H1c \\
\hline $\begin{array}{l}\text { OPC to } \\
\text { PDS }\end{array}$ & $\begin{array}{l}-5.813 \\
(* * *)\end{array}$ & & & & & & & & H1d \\
\hline $\begin{array}{l}\text { OPC to } \\
\text { CDS }\end{array}$ & $\begin{array}{l}-6.528 \\
(* * *)\end{array}$ & & & & & & & & H1e \\
\hline PsyCap & & & & & & & & & \\
\hline $\begin{array}{l}\text { Component } \\
\text { to LAS }\end{array}$ & & 3.634 & .852 & .046 & .079 & .815 & .836 & .0716 & \\
\hline $\begin{array}{l}\text { ASE to } \\
\text { LAS }\end{array}$ & $\begin{array}{c}-2.188 \\
(*)\end{array}$ & & & & & & & & $\mathrm{H} 2 \mathrm{a}$ \\
\hline OM to LAS & -.718 & & & & & & & & $\mathrm{H} 2 \mathrm{~b}$ \\
\hline HP to LAS & $\begin{array}{l}-3.883 \\
(* * *)\end{array}$ & & & & & & & & $\mathrm{H} 2 \mathrm{c}$ \\
\hline $\begin{array}{l}\text { ARS to } \\
\text { LAS }\end{array}$ & $\begin{array}{c}-2.317 \\
(*)\end{array}$ & & & & & & & & $\mathrm{H} 2 \mathrm{~d}$ \\
\hline $\begin{array}{l}\text { Suggested } \\
\text { Values }\end{array}$ & & $2-5$ & $>.8$ & $<.08$ & $<.1$ & $>.8$ & $>.8$ & $<.1$ & \\
\hline
\end{tabular}

\subsection{Finding and discussion}

The focus of this study was to explore the relationship of overall PsyCap which was developed and applied in organizational behavior studies to the learning and adaptive stress with college freshmen in educational context. Secondly, overall construct and individual component of PsyCap and learning/adaptive stress were reciprocally tested to verify the different predictabilities between each other. The testing demonstrated that only hypothesis $1 \mathrm{~b}$ was not supported and numerous of meaningful findings were disclosed by this testing as below.

First, overall PsyCap was found negatively associated with learning and adaptive stress in educational setting. Similar to the result revealed by initially application in organizational studies, PsyCap is a critical positive psychological resource in combating stress (Avey et al., 2009). It essentially enhances first-grade students in dealing with their learning and adaptive stress caused by the transition to university. This result extended and reinforced the finding across different disciplines from organizational behavior to educational context. 
In the testing of overall PsyCap to individual component of learning and adaptive stress, except the living expense stress, results showed learning problem, relationships, personality distress, and career development stresses were significantly negative affected by PsyCap. It revealed that higher level of PsyCap students may have the abilities to enhance their psychological resource to discover outside aids such as academician and peers aids to deal with learning problem, and some recommendations from academician, peers, or even professional consultations to deal with the relationships, personality distress, and career development stresses. As living expense stress is a kind of realistic issues, which may be not coped easily by the psychological resource from first-grade students who may be still lack of realistic abilities and powers to respond their own expense in college life.

Finally, overall PsyCap was found greater predictabilities than its individual component on the learning and adaptive stress. It revealed a similar finding with an organizational study. Larson and Luthans (2006) suggested a similar assumption to examine the predictability of overall Psycap to the work attitudes from employees. Except the hope hypothesis, overall PsyCap was found a greater effectiveness on the employees' work attitudes than individual state. However, the findings of this study reinforced the argument by Larson and Luthans (2006), when the positive organizational behavior (POB) variables are combined into a core construct, overall PsyCap may become a stronger predictor than any one of the four components individually. Again, the findings of PsyCap predictabilities are extended from organizational behavior studies into the educational setting.

\subsection{Theoretical implications}

Since lack of PsyCap studies in educational setting, this study intended to examine this critical resource of combating stress (Avey et al., 2009) from organizational application with participants of college freshmen. The results disclosed that PsyCap not only combats employees' stress, but also works in academic setting. This result contributes to fit the theoretical gaps of PsyCap in educational studies and revealed PsyCap variable can be implemented into cross disciplines from organizational studies to academic setting.

Another important finding of stronger predictabilities of overall PsyCap than its separated components in this study, which is complied with the argument of Larson and Luthans (2006) that while positive organizational behavior (POB) variables are combined into a core construct, overall PsyCap may become a stronger predictor than any one of the four components individually. According to the coping strategies to stress, academic self-efficacy and hope may enhance students to struggle with stress events that may call "problem focused" strategies, while optimism and academic resilience may encourage students to adjust their emotions and recognitions of the meaning of the stress events that may call "emotion focused" strategies. However, self-efficacy is fostered accumulatively by the particular successes which experienced by individual in the pass, while hope contains "willpower" and "waypower" thinking of how individual determinates one's goals and create alternative pathways and contingency plans to achieve a goal with barriers. Without energetic "problem focused" capabilities, too much optimism and resilience may only make people feeling confidence but helpless to the stress events. The findings contribute to reinforce the 
conception of synergistic effectiveness of combination each state of overall PsyCap into a core construct theoretically.

\subsection{Implications for practice}

In accordance with the study results, this study contributes the critical role of PsyCap in dealing with learning and adaptive stress in college freshmen context. In practice, academies may effort to enhance the PsyCap resource of students to deal with their stress particularly in their first year of college life. Concretely, academies may pay attention in offering extra aids in academic activities and leading students in personal goal setting to foster students' academic self-efficacy and hope capabilities (willpower and waypower). Except necessary activities to offer chances to promote students' social contact, academies may consider in offering professional consultations resources to encourage students' optimism and resilience to cope the learning and adaptive stress in the first university year.

Besides, the finding of greater effectiveness of overall PsyCap to the stress conditions remind academies may not consider only single factor in dealing with students' learning and adaptive stress. Academies should pay more attention to enhance each individual component of psychological resources of students that may cause the synergistic effectiveness to deal with the learning and adaptive stress, in turn, to enhance their academic achievement.

The only one unsupported hypothesis revealed the PsyCap has no effectiveness to deal with the living expense stress of the college freshmen. Because of the realistic matter of living expense stress may not be easily coped by only students' psychological resource. In practical, aiding resource may become important for those students who may be still lack of realistic abilities and powers to respond their own expense in university years. Except the important system of policy loan for students by government, academies may effort in seeking more scholarship resources, offering more opportunities of assistant jobs related to academic matters, and establishing well vital functions in school filed which cost lower than outside to decrease students' living expense pressure.

\section{Conclusions and limitations of this study}

As the study findings, some limitations of this study should be taken into consideration. First, data was rated and collected from individual level by self-report may cause "social desirability bias" and "common method bias" problems. We suggest future researchers to utilize different source (eg. techers) and rating methodologies for analytic strategy. Participants were from the Department of International Business Management, particularly the first-grade students. Study results may not be assumed into other participation groups. Future studies may aim to the other populations such as different grade, discipline, college, and different region. Besides, PsyCap and stress variables may be affected by demographic factors such as family backgrounds. Future studies may implement more control variables to know demographic difference on PsyCap and stress.

In accordance with the purposes of this study, the finding confirmed that PsyCap as an organizational variable effectively affects the learning and adaptive stress of first-grade college freshmen . The notion of combined positive organizational behavior (POB) variables 
may become a strong predictor was also validated into core construct, PsyCap, in educational setting. In conclusion, this study contributed to provide the important perception of PsyCap as an important resource in combating with stress across different disciplines, and, in both theoretical and practical implications.

\section{References}

Adlaf, E. M., Gliksman, L., Demers, A., \& Newton-Taylor, B. (2001). The prevalence of elevated psychological distress among Canadian undergraduates: Findings from the 1998 Canadian campus survey. Journal of American College Health, 50, 67-72. http://dx.doi.org/10.1080/07448480109596009

Affleck, G., \& Tennen, H. (1996). Construing benefits from adversity: Adaptational significance and dispositional underpinnings. Journal of Personality, 64(4), 899-922. http://dx.doi.org/10.1111/j.1467-6494.1996.tb00948.x

Avey, J. B., Luthans, F., \& Jensen, S. (2009). Psychological capital: A positive resource for combating stress and turnover. Human Resource Management, 48(5), 677-693. http://dx.doi.org/10.1002/hrm.20294

Bandura, A. (1982). Self-efficacy mechanism in human agency. American Psychologist, 37(2), 122-147. http://dx.doi.org/10.1037/0003-066X.37.2.122

Bandura, A. (1993). Perceived self-efficacy in cognitive development and functioning. Educational Psychologist, 28(2), 117-149. http://dx.doi.org/10.1207/s15326985ep2802_3

Bandura, A. (1997). Self-efficacy: The Exercise of Control. New York: Freeman.

Bandura, A. (2008). An Agentic Perspective on Positive Psychology. In S. J. Lopez (Ed.), Positive psychology: Exploring the best in people (Vol. 1, pp. 167-196). Westport, CT: Greenwood Publishing.

Bandura, A., Caprara, G. V., Barbaranelli, C., Gerbino, M., \& Pastorelli, C. (2003). Impact of affective self-regulatory efficacy on diverse sphere of functioning. Child Development, 74, 1-14. http://dx.doi.org/10.1111/1467-8624.00567

Beck, D., \& Srivastava, R. (1991). Perceived level and sources of stress in baccalaureate nursing students. The Journal of Nursing Education, 30(3), 127-133.

Bong, M. (2001). Role of self-efficacy and task-value in predicting college students' course performance and future enrollment intentions. Contemporary Educational Psychology, 26(4), 553-570. http://dx.doi.org/10.1006/ceps.2000.1048

Brown, H., \& Edelmann, R. (2000). Project 2000: A study of expected and experienced stressors and support reported by students and qualified nurses. Journal of Advanced Nursing, 31(4), 857-864. http://dx.doi.org/10.1046/j.1365-2648.2000.01344.x

Burnard, P., Rahim, T. A., Hayes, D., \& Edwards, D. (2007). A descriptive study of Bruneian student nurses; perception of stress. Nursing Education Today, 27(7), 808-818. http://dx.doi.org/10.1016/j.nedt.2006.11.002 
Carver, C. S., \& Scheier, M. S. (2002). Optimism. In C. R. Snyder \& S. J. Lopez (Eds.), Handbook of positive psychology (pp. 231-243). Oxford, UK: Oxford University Press.

Disch, W. B., Harlow, L. L., Campbell, J. F., \& Dougan, T. R. (2000). Student functioning concerns and socio-personal well-being. Social Indicators Research, 51, 41-74. http://dx.doi.org/10.1023/A:1007013820439

Dunkel-Schetter, C., \& Lobel, M. (1990). Stress in students. New Directions For Student Services, 49, 17-34. http://dx.doi.org/10.1002/ss.37119904904

Evans, W., \& Kelly, B. (2004). Pre-registration diploma student nurse stress and coping measures. Nurse Education Today, 24(6), 473-482. http://dx.doi.org/10.1016/j.nedt.2004.05.004

Folkman, S., \& Lazarus, R.S., (1985). If it changes it must be a process: Study of emotion and coping during three stages of a college examination. Journal of Personality and Social Psychology, 48 (1), 150-170. http://dx.doi.org/10.1037/0022-3514.48.1.150

Folkman, S., \& Moskowitz, J. T. (2004). Coping: Pitfalls and promise. Annual Review in Psychology, 55, 745-774. http://dx.doi.org/10.1146/annurev.psych.55.090902.141456

Gall, T. L., Evans, D. R., \& Bellerose, S. (2000). Transition to first-year university: Patterns of change in adjustment across life domains and time. Journal of Social and Clinical Psychology, 19(4), 544-567. http://dx.doi.org/10.1521/jscp.2000.19.4.544

Gayles, J. (2005). Playing the game and paying the price: Academic resilience among three high-achieving African American males. Anthropology and Education Quarterly, 36(3), 250-264. http://dx.doi.org/10.1525/aeq.2005.36.3.250

Hackett, G., Betz, N. E., Casas, J. M., \& Rocha-Singh, I. A. (1992). Gender, ethnicity, and social cognitive factors predicting the academic achievement of students in engineering. $\begin{array}{llll}\text { Journal of } \quad \text { Counseling 39(4), } & \text { 527-538. }\end{array}$ http://dx.doi.org/10.1037/0022-0167.39.4.527

Jones, M., \& Johnston, D. (2000). Reducing distress in first level and student nurses: Areview of the applied stress management literature. Journal of Advanced Nursing, 32(1), 66-74. http://dx.doi.org/10.1046/j.1365-2648.2000.01421.x

Katz, M. H. (1999). Multivariable Analysis: A Practical Guide for Clinicians. UK: Cambridge University Press.

Ko, M. J., Yu, S. J., Kim, Y. G. (2003). The effects of solution-focused group counseling on the stress response and strategies in the delinquent juveniles. Journal of Korean Academy of Nursing, 33(3), 440-450.

Larson, M., \& Luthans, F. (2006). Potential added value of psychological capital in predicting work attitudes. Journal of Leadership and Organizational Studies, 13(1), 45-62. http://dx.doi.org/10.1177/10717919070130010701

Lazarus, R. S. (2003). Does the positive psychology movement have legs? Psychological 
Inquiry, 14(2), 93-109. http://dx.doi.org/10.1207/S15327965PLI1402_02

Lazarus, R. S., \& Folkman, S. (1984). Stress, Appraisal, and Coping. New York: Springer.

Lin, J. S. (2005). The validity and reliability of the learning and adaptive stress scale(LASS): A pilot data analysis. 2005 International Conference on Education and Information Technology, $9^{\text {th }}-10^{\text {th }}$ Dec., Keelung, Taiwan.

Lorsbach, A. W., \& Jinks, J. (1999). Self-efficacy theory and learning environment research. Learning Environments Research, 2(2), 157-167. http://dx.doi.org/10.1023/A:1009902810926

Luthans, F. (2002). The need for and meaning of positive organizational behavior. Journal of Organizational Behavior, 23(6), 695-706. http://dx.doi.org/10.1002/job.165

Luthans, F., Avolio, B. J., Avey, J. B., \& Norman, S. M. (2007). Positive psychological capital: Measurement and relationship with performance and satisfaction. Personnel Psychology, 60(3), 541-572. http://dx.doi.org/10.1111/j.1744-6570.2007.00083.x

Luthans, F., Norman, S. M., Avolio, B. J., \& Avey, J. B. (2008). The mediating role of psychological capital in the supportive organizational climate-employee performance relationship. Journal of Organizational Behavior, 29(2), 219-238. http://dx.doi.org/10.1002/job.507

Luthans, F., Youssef, C. M., \& Avolio, B. J. (2007). Psychological Capital: Developing the Human Competitive Edge. New York: Oxford University Press.

Mallinckrodt, B. (1988). Student retention, social support, and dropout intention: Comparison of black and white students. Journal of College Student Development, 29(1), 60-64.

Martin, A. J., \& Marsh, H. W. (2006). Academic resilience and its psychological and educational correlates: A construct validity approach. Psychology in the Schools, 43(3), 267-281. http://dx.doi.org/10.1002/pits.20149

McDermott, D., \& Snyder, C. R. (2000). The Great Big Book of Hope: Help Your Children Achieve Their Dreams. Oakland, CA: New Harbinger Publications.

McKenzie, K., \& Schweitzer, R. (2001). Who succeeded at university? Factors predicting academic performance in first year Australian university students. Higher Education Research \& Development, 20 (1), 21-33. http://dx.doi.org/10.1080/07924360120043621

Multon, K. D., Brown, S. D., \& Lent, R. W. (1991). Relation of self-efficacy beliefs to academic outcomes: A meta-analytic investigation. Journal of Counseling Psychology, 38(1), 30-38. http://dx.doi.org/10.1037/0022-0167.38.1.30

Muris, P. (2001). A brief questionnaire for measuring self-efficacy in youths. Journal of Psychopathology and Behavioral Assessment, 23(3), 145-149. http://dx.doi.org/10.1023/A:1010961119608

Newbury-Birch, D., Lowry, R. J., \& Kamali, F. (2002). The changing patterns of drinking, 
illicit drug use, stress, anxiety and depression in dental students in UK dental school: A longitudinal study. British Dental Journal, 192(11), 646-649. http://dx.doi.org/10.1038/sj.bdj.4801448

Onwuegbuzie, A. J., \& Snyder, C. R. (2000). Relations between hope and graduate students' coping strategies for studying and examination-taking. Psychological Reports, 86, 803-806. http://dx.doi.org/10.2466/pr0.2000.86.3.803

Park, C. (1998). Stress-related growth and thriving through coping: The roles of personality and cognitive processes. Journal of Social Issues, 54, 267-277. http://dx.doi.org/10.1111/j.1540-4560.1998.tb01218.x

Raj, S. R., Simpson, C. S., Hopman, W. M., \& Singer, M. A. (2000). Health-related quality of life among final-year medical students. Canadian Medical Association, 162(4), 509-510.

Scheier, M. F., Carver C. S., \& Bridges, M. W. (1994). Distinguishing optimism from neuroticism (and trait anxiety, self-mastery, and self-esteem): A re-evaluation of the Life Orientation Test. Journal of Personality and Social Psychology, 67, 1063-1078. http://dx.doi.org/10.1037/0022-3514.67.6.1063

Schulz, H., Vögele, C., \& Meyer, B. (2009). Optimism, self-efficacy, and perceived stress as predictors of self-reported health symptoms in college students. Zeitschrift fur Gesundheitspsychologie, 17(4), 185-194. http://dx.doi.org/10.1026/0943-8149.17.4.185

Seligman, M. E. P. (1998). Learned Optimism. New York: Pocket Books.

Shek, D. T. L. (1995). Adolescent mental health in different Chinese societies. International Journal of Adolescent Medicine and Health, 8(2), 117-155.

Shepperd, J. A., Maroto, J. J., \& Pbert, L. A. (1996). Dispositional optimism as a predictor of health changes among cardiac patients. Journal of Research in Personatity, 30, 517-534. http://dx.doi.org/10.1006/jrpe.1996.0038

Sheu, S., Lin, H., \& Hwang, S. (2002). Perceived stress and physiopsycho-social status of nursing students during their initial period of clinical practice: The effect of coping behaviors. International Journal of Nursing Studies, 39, 165-175. http://dx.doi.org/10.1016/S0020-7489(01)00016-5

Snyder, C. R. (2000). Handbook of Hope. San Diego: Academic Press.

Snyder, C. R., Irving, L. M., \& Anderson, J. R. (1991). Hope and health. In C. R. Snyder (Ed.), Handbook of social and clinical psychology (pp. 285-305). Oxford: Oxford University Press.

Snyder, C. R., Lopez, S., Shorey, H. S., Rand, K. L., \& Feldman, D. B. (2003). Hope theory, measurements and applications to school psychology. School Psychology Quarterly, 18(2), 122-139. http://dx.doi.org/10.1521/scpq.18.2.122.21854

Snyder, C. R., Sympson, S. C., Ybasco, F. C., Borders, T. F., Babyak, M. A., \& Higgins, R. L. (1996). Development and validation of the State Hope Scale. Journal of Personality and 
Social Psychology, 2, 321-335. http://dx.doi.org/10.1037/0022-3514.70.2.321

Stajkovic, A. D., \& Luthans, F. (1998). Social cognitive theory and self efficacy: Going beyond traditional motivational and behavioral approaches. Organizational Dynamics, 26(4), 62-74. http://dx.doi.org/10.1016/S0090-2616(98)90006-7

Stewart-Brown, S., Patterson, J., Petersen, S., Doll, H., Balding, J., \& Regis, D. (2000). The health of students in institutes of higher education: An important and neglected public health problem? Journal of Public Health Medicine, 22 (4), 492-499. http://dx.doi.org/10.1093/pubmed/22.4.492

Towbes, L., \& Cohen, L. (1996). Chronic stress in the lives of college students: Scale development and prospective prediction of distress. Journal of Youth and Adolescence, 25(2), 199-217. http://dx.doi.org/10.1007/BF01537344

Trusty, J. (2000). High educational expectations and low achievement: Stability of educational goals across adolescence. The Journal of Educational Research, 93(6), 356-365. http://dx.doi.org/10.1080/00220670009598730

Tugade, M. M., \& Fredrickson, B. L. (2004). Resilient individuals use positive emotions to bounce back from negative emotional experiences. Journal of Personality and Social Psychology, 86(2), 320-333. http://dx.doi.org/10.1037/0022-3514.86.2.320

Vaez, M., \& Laflamme, L. (2008). Experienced stress, psychological symptoms, self-rated health and academic achievement: A longitudinal study of Swedish university students. Social Behavior and Personality, 36(2), 183-196. http://dx.doi.org/10.2224/sbp.2008.36.2.183

Wagnild, G. M., \& Young, H. M. (1993). Development and psychometric evaluation of the resilience scale. Journal of Nursing Measurement, 1(2), 165-178.

Weissberg, R. P., \& O’Brien, M. U. (2004). What works in school-based social and emotional learning programs for positive youth development. Annals of the American Academy of Political and Social Science, 591(1), 86-97. http://dx.doi.org/10.1177/0002716203260093 